\title{
Deep inguinal infection following coronary angioplasty: Report of two cases
}

\section{Esra Polat ${ }^{1}$, Ibrahim Halil Inanc ${ }^{2}$ \\ ${ }^{1}$ Department of Cardiology, Fethiye State Hospital, Fethiye, Muğla, Turkey \\ ${ }^{2}$ Department of Cardiology, Besni State Hospital, Adiyaman, Turkey}

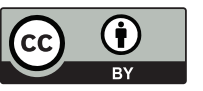

This work is licensed under a Creative Commons Attribution 4.0 International License

Received: 2020-03-21

Accepted: 2020-04-01

UDC: 616.1

J Clin Med Kaz 2020; 2(56):53-55

Corresponding Author: Esra Polat, MD, Department of Cardiology, Fethiye State Hospital, Fethiye, Muğla, Turkey. Tel.: +90538 5899772

E-mail: esrapolat-1907@hotmail.com

\section{Abstract}

Cardiac catheterization is a common method for diagnostic and therapeutic purposes. The frequency of arterial complications after cardiac catheterizations from the femoral region is observed as $0.23 \%$. Although bleeding, hematoma, pseudoaneurysm and arterial thrombosis are more frequent after cardiac catheterization, intervention site infection can rarely be seen as a complication.

We describe two patients with deep inguinal infections after repetitive interventions from ipsilateral femoral region.

Key words: angioplasty, inguinal infection

КОРОНАРЛЫҚ АНГИОПЛАСТИКАДАН КЕЙІНГІ ТЕРЕН ШАП ИНФЕКЦИЯСЫ: ЕКІ КЛИНИКАЛЫҚ ЖАҒДАЙДЫН СИПАТТАМАСЫ

Э. Полат ${ }^{1}$, И.Х. Инанч'

'Кардиология бөлімі, Фетхие Мемлекеттік ауруханасы, Мугла, Түркия

${ }^{2}$ Кардиология бөлімі, Бесни Мемлекеттік ауруханасы, Адыяман, Түркия

\section{ТҰЖЫРЫМДАМА}

Жүректің катетеризациясы диагностикалық және емдік мақсаттағы кең таралған әдіс болып табылады. Феморальды аймақта жүрек катетеризациясынан кейінгі артериялық асқынулар жиілігі 0,23\% құрайды. Жүрек катетеризациясынан кейін қан кету, гематома, псевдоаневризма және артериялық тромбоз жиі кездесетініне қарамастан, араласу орнында инфекция сирек асқыну болып саналады. Бұл зерттеу екіжақты жамбас аймағында бірнеше рет араласқаннан кейін терең шап инфекциясы бар екі науқастың жағдайын сипаттайды.

Негізгі сөздер: ангиопластика, шап иноекциясы

\section{ГЛУБОКАЯ ПАХОВАЯ ИНФЕКЦИЯ ПОСЛЕ КОРОНАРНОЙ АНГИОПЛАСТИКИ: ОПИСАНИЕ ДВУХ КЛИНИЧЕСКИХ СЛУЧАЕВ}

\section{Э. Полат ${ }^{1}$, И.Х. Инанч ${ }^{2}$}

'Отделение кардиологии, Государственная больница Фетхие, Мугла, Турция

${ }^{2}$ Отделение кардиологии, Государственная больница Бесни, Адыяман, Турция

\section{PЕЗЮME}

Катетеризация сердца является распространенным методом в диагностических и терапевтических целях. Частота артериальных осложнений после катетеризации сердца в бедренной области составляет 0,23\%. Несмотря на то, что после катетеризации сердца чаще встречаются кровотечение, гематома, псевдоаневризма и артериальный тромбоз, инфекция в месте вмешательства крайне редко может рассматриваться как осложнение. В настоящем исследовании описывается случаи двух пациентов с глубокими паховыми инфекциями после повторных вмешательств в ипсилатеральной области бедра.

Ключевые слова: ангиопластика, паховая инфекция 


\section{Introduction}

Cardiac catheterization is a frequently used method for diagnostic and therapeutic purposes. Although our country is a middle-income country, coronary angiography and percutaneous coronary intervention are widely used as in high-income countries [1]. As an increasing number of cardiac catheterization, intervention related complications are reported more frequently. Bleeding, hematoma, pseudoaneurysm, arterial thrombosis are common complications [2].

Here in, we presented the cases of deep inguinal infections, which are rarely seen after cardiac catheterization.

\section{Case presentations \\ Case 1}

A 63-year-old patient with known hypertension was diagnosed with Non ST segment elevation myocardial infarction (NSTEMI). Coronary angiography and percutaneous coronary intervention (PCI) was performed for critical stenosis of circumflex $(\mathrm{Cx})$ artery. Because of persistent chest pain PCI was performed for critical left anterior descending (LAD) 24 hours later.

On the first month of his follow up, physical examination revealed a purulent wound with a size of $2 \times 2 \mathrm{~cm}$ in the right femoral puncture area destructing cutaneous tissue. Also, tissue around the wound was hyperemic (Figure 1).

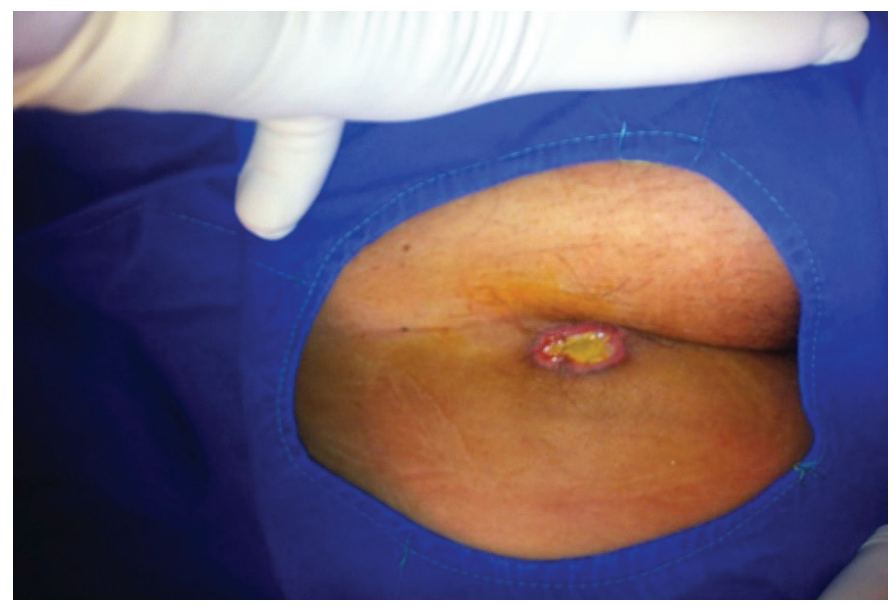

Figure 1

His general and other systemic examination were unremarkable. Ciprofloxacin and ampicillin-sulbactam were administered as empirical treatment with the recommendation of the infection department until the culture results were obtained. Debridement was performed by the plastic surgeon. Culture results confirmed enterococcus faecalis ve escheria coli infection. Meropenem was replaced with former antibiotics as an antibiotherapy according to the antibiogram results.

Local dressings were performed with rifampicin during hospital stay. The patient was discharged with oral cefuroxime and dressing recommendations after 14 days of intravenous antibiotherapy. At the first week check, the wound was clean.

\section{Case 2}

Coronary angiography was performed with a diagnosis of acute coronary syndrome in a 69 -year-old patient with a history of coronary artery bypass surgery and right coronary artery (RCA) PCI was performed. After 10 hours of intervention, because of suspicion of stent thrombosis, coronary angiography was performed again. Right femoral region was used in both interventions.
On the second week of his follow up, physical examination revealed a purulent wound with a size of $3.0 \times 1.5 \mathrm{~cm}$ in the right femoral puncture area destructing cutaneous tissue (Figure 2).

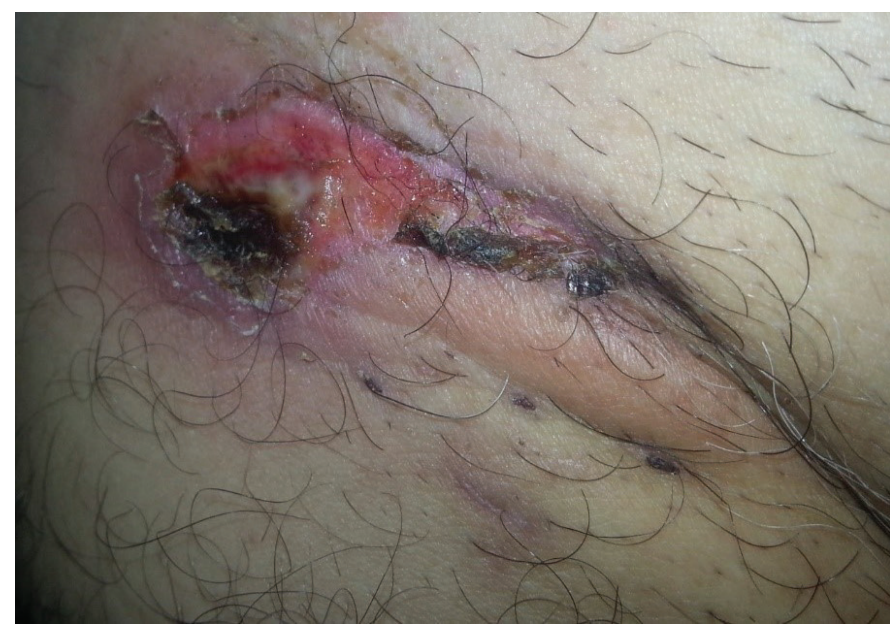

Figure 2

Intravenous ciprofloxacin and oral amoxocillin-clavulanate were administered as empirical treatment. Culture results confirmed Staphylococcus aureus infection. After discharging with oral ciprofloxacin and amoxicillin-clavunalate, the wound was clean at the first week check.

\section{Discussion}

The frequency of arterial complications after cardiac catheterizations from the femoral region is observed as $0.23 \%$ [3]. Bleeding, hematoma, pseudoaneurysm and arterial thrombosis are frequently seen complications [2]. Infection at the intervention site is a rare complication after cardiac catheterization. The most common microorganism causing infection is Staphylococcus aureus [4]

In one of our cases, Staphylococcus aureus was the cause of infection in accordance with the literature, and in the other, Escherichia coli, which is rarely the cause of soft tissue infection, was observed.

The reason why Escherichia coli was seen as a factor in our case may be due to the transfer of Escherichia coli in the intestinal flora to the femoral region.

Re-using of the previous intervention area in the early period, long stay of the femoral sheath, bleeding or hematoma in the femoral sheath placement area and using percutaneous suture mediated closure devices are major risk factors for infectious complications after cardiac catheterizations $[5,6]$. In the both two our cases, there were two interventions from the same femoral region for two consecutive days. Contralateral region is recommended to be used in case of recatheterization. Administration of prophylactic antibiotics may be considered if ipsilateral catheterization is planned [4].

In conclusion, in order to prevent infection after coronary angiography, it is recommended to pay attention to hygiene, and to use the opposite femoral region in repetitive interventions.

Disclosures: There is no conflict of interest for all authors.

Patient informed consent: obtained. 


\section{References}

1. Timmis A, Townsend N, Gale C, Grobbee R, Maniadakis N, Flather M, et al. European Society of Cardiology: cardiovascular disease statistics 2017. European heart journal. 2018; 39(7):508-79. https://doi.org/10.1093/eurheartj/ehx628

2. Paganin AC, Beghetto MG, Feijó MK, Matte R, Sauer JM, Rabelo-Silva ER. Vascular complications in patients who underwent endovascular cardiac procedures: multicenter cohort study. Revista latino-americana de enfermagem. 2018; 26. https://doi. org/10.1590/1518-8345.2672.3060

3. Babu SC, Piccorelli GO, Shah PM, Stein JH, Clauss RH. Incidence and results of arterial complications among 16,350 patients undergoing cardiac catheterization. Journal of vascular surgery. 1989; 10(2):113-6. https://doi.org/10.1016/07415214(89)90342-X

4. Frazee BW, Flaherty JP. Septic endarteritis of the femoral artery following angioplasty. Reviews of infectious diseases. 1991; 13(4):620-3. https://doi.org/10.1093/clinids/13.4.620

5. Cleveland KO, Gelfand MS. Invasive staphylococcal infections complicating percutaneous transluminal coronary angioplasty: three cases and review. Clinical infectious diseases. 1995; 21(1):93-6. https://doi.org/10.1093/clinids/21.1.93

6. Polgreen PM, Diekema DJ, VandeBerg J, Wiblin RT, Chen YY, David S, et al. Risk Factors for Groin Wound Infection After Femoral Artery Catheterization A Case-Control Study. Infection Control \& Hospital Epidemiology. 2006; 27(1):34-7. https://doi. org/10.1086/500001

How to cite this article: Esra Polat, Ibrahim Halil Inanc. Deep inguinal infection following coronary angioplasty : Report of two cases. J Clin Med Kaz. 2020; 2(56):53-55 